\title{
Malignant solitary fibrous tumor of the thyroid: a case-report and review of the literature
}

\author{
Tumor fibroso solitário maligno da tiroide: \\ relato de caso e revisão da literatura
}

\begin{abstract}
Wellington Alves Filho', Renata Regina da Graça Lorencetti Mahmoud', Daniel Marin Ramos', Vergilius José Furtado de Araujo-Filho', Patricia Picciarelli de Lima², Claudio Roberto Cernea', Lenine Garcia Brandão'
\end{abstract}

\begin{abstract}
Department of Head and Neck Surgery, University of Sao Paulo, School of Medicine (FMUSP), Sao Paulo, SP, Brazil 2 Department of Pathology, FMUSP, Sao Paulo, SP, Brazil
\end{abstract}

Correspondence to: Wellington Alves Filho Rua Apeninos, 800, ap. 413 04104-020 - São Paulo, SP, Brazil wellington_a@hotmail.com

Received on Jan/15/2014 Accepted on Fev/27/2014 DOI: $10.1590 / 0004-2730000003230$

\begin{abstract}
SUMMARY
Solitary fibrous tumor (SFT) is an uncommon spindle-cell neoplasm that most often involves the pleura, rarely occurring in extra-thoracic locations. Twenty-six cases of SFT arising in the thyroid gland have been described. We report a case of a 60 -year-old woman presenting an 8-month history of enlargement of the neck associated with dysphagia. The patient underwent a right hemithyroidectomy and SFT of the thyroid was diagnosed. Immunohistochemistry showed positivity for CD34 marker, and the high number of mitoses and the presence of cellular atypia suggested that the tumor was malignant. To our knowledge, this is the second case of malignant SFT of the thyroid gland ever reported. Due to the rarity of these tumors, the indication of adjuvant therapy and prognosis are uncertain. Long-term follow-up after surgical resection seems to be advisable. Arq Bras Endocrinol Metab. 2014;58(4):402-6
\end{abstract}

\section{RESUMO}

O tumor fibroso solitário (SFT) é uma neoplasia rara de células fusiformes que mais frequentemente envolve a pleura, raramente ocorrendo em áreas extratorácicas. Já foram descritos 26 casos de SFT da tiroide. Relatamos o caso de uma paciente de 60 anos de idade com um histórico de 8 meses de aumento do pescoço associado à disfagia. A paciente foi submetida a uma hemitiroidectomia direita e foi diagnosticado um SFT de tiroide. A imuno-histoquímica mostrou resultados positivos para o marcador CD34, e o grande número de mitoses e a presença de atipia celular sugerem que o tumor era maligno. Em nosso conhecimento, este é o segundo caso de STF da tiroide maligno já relatado. Dada a rara ocorrência desses tumores, a indicação de tratamento adjuvante e o prognóstico são incertos. Recomenda-se o acompanhamento de longo prazo depois da ressecção cirúrgica. Arq Bras Endocrinol Metab. 2014;58(4):402-6

\section{INTRODUCTION}

S olitary fibrous tumor (SFT) is a rare spindle-cell neoplasm, originally described by Klemperer and Rabin in 1931 as a pleural tumor (1). Albeit it has been originally recognized as a localized form of mesothelioma (2), some studies have reported extrapleural sites in the body $(3,4)$, such as thyroid, salivary glands, tongue, respiratory tract, orbit, liver, meninges and retroperitoneum $(3,5)$. They are very rare in the thyroid gland, with only 26 cases described after the original report in $1993(6,7)$. Among those, only one met the criteria for malignant SFT (8), proposed by Vallat-Decouvelaere and cols. in 1998 (9). We present what appears to be the second case described of a malignant solitary fibrous tumor of the thyroid.

\section{CASE REPORT}

A 60-year-old woman presented an 8-month history of enlargement of the neck associated with dysphagia to solids. She also complained of voice hoarseness and mild respiratory symptoms, mostly at night. The pa- 
tient was referred to the Department of Head and Neck Surgery of the Hospital das Clínicas of the University of Sao Paulo, School of Medicine, in November 2012. At the physical examination, an enlargement of the right side of the neck was observed, with a homogeneous and tender consistency at palpation. The right vocal fold had reduced mobility, with an underlying submucosal mass. Thyroid function tests were normal, and the ultrasonography (US) demonstrated a right-side thyroid mass, with an intrathoracic component and reduction of the lumen of the trachea. The volume of the gland was $283.6 \mathrm{cc}$, and the left thyroid lobe appeared normal. Computed tomography (CT) findings were in accordance with the US data (Figure 1). An US-guided fine-needle aspiration biopsy (FNAB) was performed, with a benign cytopathologic result.

The patient underwent right hemithyroidectomy in January 2013, with a frozen-section analysis suspicious for thyroid lymphoma or chronic thyroiditis. The right recurrent laryngeal nerve (RLN), as well as both rightside parathyroid glands were preserved. Right after extubation in the operative room, the patient developed severe dyspnea refractory to non-invasive positive pressure ventilation. A tracheostomy was then performed.

Histopathological findings included SFT with 13.8 x $8.5 \mathrm{~cm}$, without necrotic foci and with $06 / 10$ mitoses per high-power fields (HPF). Immunohistochemistry staining showed that tumor cells strongly expressed CD34 marker, with negative expression of desmin, S100 protein, cytokeratin $35 \mathrm{BHll}$, beta-catenina, and calcitonin (Figures 2 and 3).

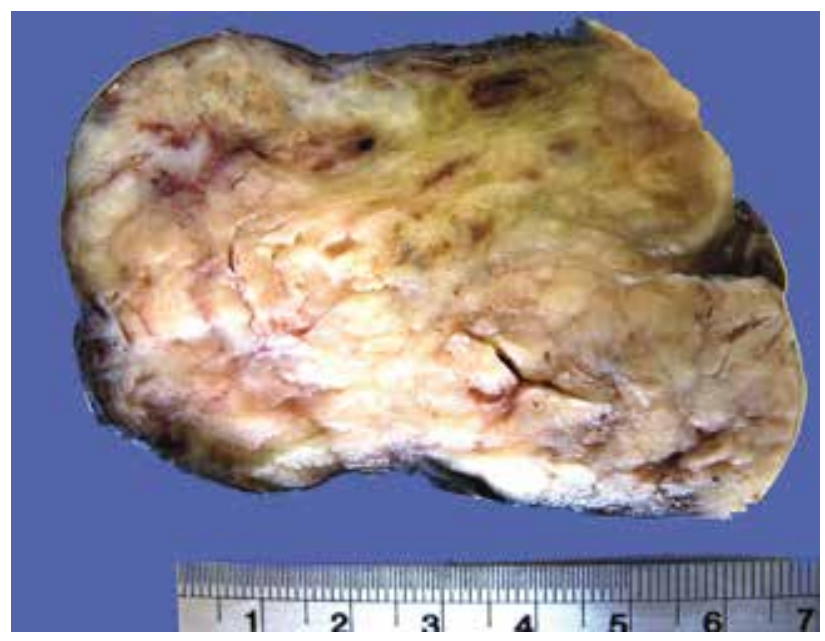

Figure 1. Tumor section surface in the thyroid gland. The tumor is irregular, with multinodular areas and white-tan color. The section surface is firm and curled.

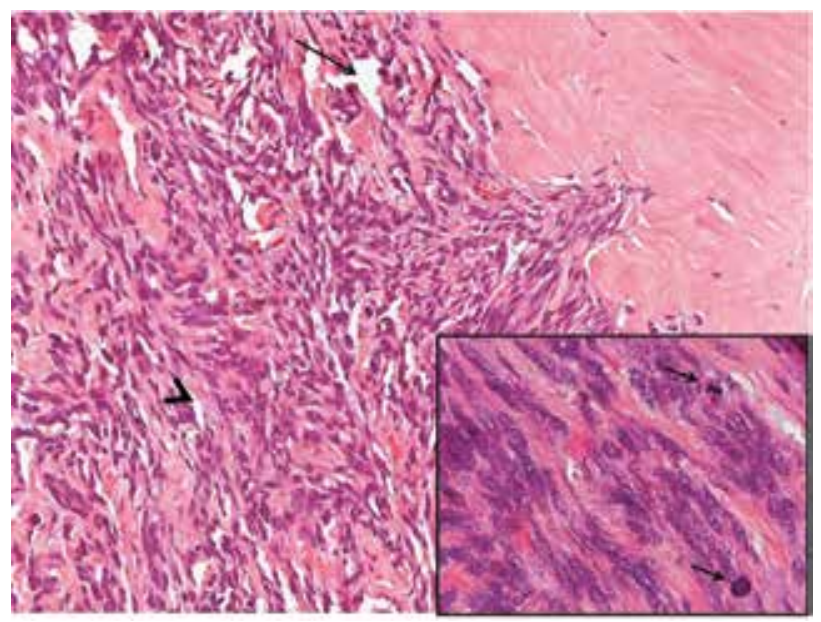

Figure 2. Histological architecture with "patternless" growth pattern. Spindle cells are separated by thick hyalinized collagen with cracking artifact (arrowhead) and hemangiopericytoma-like vessels (arrow). Note the infiltrative tumor edge (hematoxilin and eosin, 200X). Inset: spindle cells with moderate atypia and mitotic figures (arrows) (hematoxilin and eosin, 1000X).

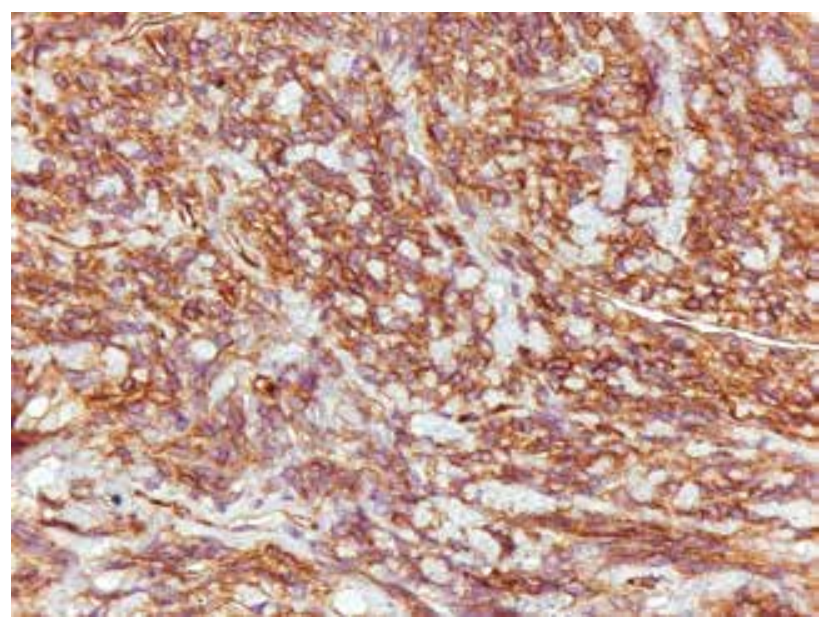

Figure 3. CD 34 immunostaining (immunoperoxidase reaction, 400X).

The patient was discharged from the hospital on the fifth postoperative day, and the tracheostomy tube was removed three weeks after the operation. She persisted with right vocal fold paralysis, with normal speech and respiration.

\section{DISCUSSION}

SFTs are rare ubiquitous neoplasms of mesenchymal origin. The etiology is unknown (10). It was described as a pleural-based lesion (1), but there were subsequent reports on other anatomic sites as well (3). 
Less than $0.1 \%$ of all tumors appear on the head and neck area (2). The first report of a SFT of the thyroid (SFT-T) was published in 1993 by Taccagni and cols. (7). Since then, to our knowledge, only 26 cases were described in the English-language literature (6). A review of these articles is summarized in table 1 .

According to cumulative data, the mean age for appearance of SFT-T is 50 years (ranging from 28 to 68 years), with no difference in gender. The size of the tumor can range from 2 to $10 \mathrm{~cm}$, and there is equal incidence for both thyroid lobes (11). The clinical presentation is similar to regular thyroid neoplasms (10). The patient usually refers to a slowly growing painless mass, but, occasionally, there may be a rapid increase in volume $(7,8)$. The present case, a 60 -year-old female patient with a $13.8 \times 8.5 \mathrm{~cm}$ tumor arising from the right thyroid lobe, had the largest SFT-T ever described.

Table 1. Review of the literature of SFT of thyroid

\begin{tabular}{|c|c|c|c|c|c|c|}
\hline Author, year (reference) & $N^{0}$ of cases & Age/Sex & Lobe & Size (cm) & $\begin{array}{c}\text { Mitoses } \\
\text { (> 4/10 HPF) }\end{array}$ & Necrosis \\
\hline Present study, 2013 & 1 & $60 / F$ & $\mathrm{R}$ & 13.8 & Y & $\mathrm{N}$ \\
\hline \multirow[t]{2}{*}{ Verdi and cols., 2011 (6) } & 2 & $47 / F$ & L & 5.2 & $\mathrm{~N}$ & $\mathrm{~N}$ \\
\hline & & $59 / M$ & $\mathrm{R}$ & 7.0 & $\mathrm{~N}$ & $\mathrm{~N}$ \\
\hline Ning and cols., 2010 (8) & 1 & $76 / F$ & $\mathrm{R}$ & 4.0 & Y & Y \\
\hline Song and cols., 2011 (15) & 1 & $37 / M$ & L & 4.0 & $\mathrm{~N}$ & $\mathrm{~N}$ \\
\hline Larsen and cols., 2010 (2) & 1 & $58 / \mathrm{M}$ & L & 8.0 & $\mathrm{~N}$ & NA \\
\hline Farrag and cols., 2009 (13) & 1 & $51 / M$ & L & 7.0 & NA & NA \\
\hline Papi and cols., 2006 (16) & 1 & $70 / F$ & $\mathrm{R}$ & 1.5 & $\mathrm{~N}$ & $\mathrm{~N}$ \\
\hline \multirow[t]{2}{*}{ Santeusanio and cols., 2008 (11) } & 2 & $61 / M$ & $\mathrm{R}$ & 3.5 & N & $\mathrm{N}$ \\
\hline & & $42 / F$ & $\mathrm{R}$ & 4.7 & $\mathrm{~N}$ & $\mathrm{~N}$ \\
\hline Babouk, 2004 (12) & 1 & $45 / M$ & $\mathrm{~L}$ & 5.0 & $\mathrm{~N}$ & $\mathrm{~N}$ \\
\hline Bohorquez and cols., 2003 (17) & 1 & $68 / M$ & $\mathrm{~L}$ & 9.7 & N & $\mathrm{N}$ \\
\hline Parwani and cols., 2003 (5) & 1 & $61 / \mathrm{M}$ & $\mathrm{L}$ & 5.0 & NA & NA \\
\hline Deshmukh and cols., 2001 (14) & 1 & $56 / M$ & $\mathrm{R}$ & 8.0 & $\mathrm{~N}$ & $\mathrm{~N}$ \\
\hline \multirow[t]{7}{*}{ Rodriguez and cols., 2001 (18) } & 7 & $43 / F$ & $\mathrm{~L}$ & 3.5 & $\mathrm{~N}$ & $\mathrm{~N}$ \\
\hline & & $52 / \mathrm{M}$ & $\mathrm{L}$ & 2.5 & $\mathrm{~N}$ & $\mathrm{~N}$ \\
\hline & & $44 / \mathrm{M}$ & $\mathrm{L}$ & 2.0 & $\mathrm{~N}$ & $\mathrm{~N}$ \\
\hline & & $64 / F$ & $\mathrm{R}$ & 4.5 & $\mathrm{~N}$ & $\mathrm{~N}$ \\
\hline & & $53 / M$ & $\mathrm{~L}$ & 6 & $\mathrm{~N}$ & $\mathrm{~N}$ \\
\hline & & $47 / F$ & $\mathrm{R}$ & 4.5 & N & $\mathrm{N}$ \\
\hline & & $64 / F$ & $\mathrm{~L}$ & 3 & $\mathrm{~N}$ & $\mathrm{~N}$ \\
\hline Brunneman and cols., 1999 (19) & 1 & $28 / F$ & NA & 2.5 & $\mathrm{~N}$ & $\mathrm{~N}$ \\
\hline Kie and cols., 1997 (4) & 1 & $48 / F$ & NA & 8.0 & $\mathrm{~N}$ & N \\
\hline Cameselle and cols., 1994 (20) & 1 & $43 / F$ & NA & 4.0 & $\mathrm{~N}$ & $\mathrm{~N}$ \\
\hline \multirow[t]{3}{*}{ Taccagni and cols., 1993 (7) } & 3 & $44 / F$ & $\mathrm{R}$ & 6.5 & N & NA \\
\hline & & $61 / M$ & $\mathrm{~L}$ & 6.0 & $\mathrm{~N}$ & NA \\
\hline & & $32 / F$ & $\mathrm{R}$ & 3.5 & $\mathrm{~N}$ & NA \\
\hline
\end{tabular}

HPF: high-power fields; SFT: solitary fibrous tumor; M: male; F: female; L: left; R: right; N: absence; Y: presence; NA: not available. 
SFT-T can only be diagnosed after exclusion of other thyroid tumors that exhibit spindle-cell morphology (12). Among the possible differential diagnosis are hemangiopericytomas, Riedel's thyroiditis, medullary carcinomas, anaplastic carcinomas, sarcomas, leiomyomas, neurofibromas, schwanomas, and lymphomas (10).

Although FNAB is a standard procedure in the evaluation of thyroid nodules, its efficacy in the diagnosis of SFT-T is limited (13). Only two reports showed a diagnosis of spindle-cell neoplasm using cytology combined with immunocytochemistry, but a definitive confirmation of SFT-T was not possible using this method alone $(5,13)$. The FNAB of the present patient showed a benign lesion, most likely granulomatous thyroiditis. Immunocytochemistry was not performed in this case, since cytology demonstrated a benign lesion. Because of FNAB limitations, proper diagnosis can only be ensured by combination of histopathological and immunohistochemistry evaluation.

Microscopically, SFT-T exhibits a unique morphology, often referred as a "patternless" pattern, with spindle cell proliferation, intermingled with hypercellular and hypocellular areas (14). At immunohistochemistry, the tumor cells revealed positivity for CD34, bcl-2, CD99, and vimentin, but not for epithelial markers (such as keratins, thyroglobulin), desmin, and S100 protein $(10,11)$.

Extra-pleural SFT-Ts are mostly benign neoplasms, and there are no distinct pathologic features to help differentiating benign from malignant lesions $(3,15)$. Some characteristics suggesting a more aggressive behavior were proposed in 1998 by Vallat-Decouvelaere and cols., and included (i) high cellularity, (ii) cytological atypia, (iii) higher frequency of mitoses $(>4 / 10$ $\mathrm{HPF}$ ), (iv) evidence of tumor necrosis or infiltrating margins (9). So far, there is only one report of malignant SFT-T, which already presented pulmonary metastasis when diagnosed (8). In the present case, even without distant metastasis, the tumor presented two of the above-cited criteria for malignancy (cytological atypia and > 4/10 mitoses per HPF). With these findings, we believe that our case is the second report of malignant SFT-T.

The management of SFT-T is primarily surgical, which also provides a definitive diagnosis $(10,13)$. If there is no suspicion of malignancy, such as invasion of surrounding structures, a thyroid lobectomy may be sufficient. In the present case, we did not find any intraoperative sings of malignancy. Due to the preoperative right vocal fold paresis, combined with the intraopera- tive finding of a normal left lobe, we chose to perform a right hemithyroidectomy. In such cases of preoperative vocal fold impairment, it is recommended that the surgical procedure starts by the exploration of the side of the neck that is ipsilateral to the paresis, as long as this does not affect the oncologic aspects of the operation (i.e., removal of the lobe containing the lesion). Even with an intact left RLN, the patient developed important dyspnea in the recovery room, and a tracheostomy was then performed. The patient received steroids in the postoperative period, and the tracheostomy tube was uneventfully withdrawn after 3 weeks.

TSH suppression therapy with hormones has no rationale in the management of SFT-T, as the origin of tumor cells is stromal (8). The indication of chemotherapy or external radiation therapy is controversial, even in malignant tumors $(8,10)$.

Because of the rarity of these tumors, especially in cases of malignancy, not much is known about its behavior or prognosis. Close follow-up after surgical resection of lesions seems to be the best management.

In conclusion, this is the $27^{\text {th }}$ reported case of SFT-T in the English-language literature, being the second malignant tumor reported, and the larger lesion described so far.

Disclosure: no potential conflict of interest relevant to this article was reported.

\section{REFERENCES}

1. Klemperer P, Rabin CB. Primary neoplasm of the pleura: a report of five cases. Arch Pathol. 1931;11:385-412.

2. Larsen SR, Godballe C, Krogdahl A. Solitary fibrous tumor arising in an intrathoracic goiter. Thyroid. 2010;20(4):435-7.

3. Chan JKC. Solitary fibrous tumor - everywhere, and a diagnosis in vogue. Histopathology. 1997;31:568-76.

4. Kie JH, Kim JY, Park YN, Lee MK, Yang WI, Park JS. Solitary fibrous tumor of the thyroid. Histopathology. 1997;30:365-8.

5. Parwani AV, Galindo R, Steinberg DM, Zeiger MA, Westra WH, Ali SZ. Solitary fibrous tumor of the thyroid: cytopathologic findings and differential diagnosis. Diagn Cytopathol. 2003;28:213-6.

6. Verdi D, Pennelli G, Pelizzo MR, Toniato A. Solitary fibrous tumor of the thyroid gland: a report of two cases with an analysis of their clinical and pathological features. Endocr Pathol. 2011;22:165-9.

7. Taccagni G, Sambade C, Nesland J,Terreni MR, Sobrinho-Simoes M. Solitary fibrous tumour of the thyroid: clinicopathological, immunohistochemical and ultrastructural study of three cases. Virchows Arch A Pathol Anat Histopathol. 1993;422:491-7.

8. Ning S, Song X, Xiang L, Chen Y, Cheng Y, Chen H. Malignant solitary fibrous tumor of the thyroid gland. Diagn Cytopathol. 2010;39:694-9.

9. Vallat-Decouvelaere AV, Dry SM, Fletcher CDM. Atypical and malignant solitary fibrous tumors in extrathoracic locations: evidence of their comparability to intra-thoracic tumors. Am J Surg Pathol. 1998;22:1501-11. 
10. Papi G, Corrado S, Uberti ED, Roti E. Solitary fibrous tumor of the thyroid gland. Thyroid. 2007;17:119-26.

11. Santeusanio G, Schiaroli S, Ortenzi A, Mulè A, Perone G, Fadda G. Solitary fibrous tumor of thyroid: report of two cases with immunohistochemical features and literature review. Head Neck Pathol. 2008;2:231-5.

12. Babouk NL. Solitary fibrous tumor of the thyroid gland. Saudi Med J. 2004;25:805-7.

13. Farrag TY, Micchelli S, Tufano RP. Solitary fibrous tumor of the thyroid gland. Laryngoscope. 2009;119:2306-8.

14. Deshmukh NS, Mangham DC, Warfield AT, Watkinson JC. Solitary fibrous tumor of the thyroid gland. J Laryngol Otol. 2001;115:940-2.

15. Song Z, Yu C, Song X, Wei L, Liu A. Primary solitary fibrous tumor of the thyroid - report of a case and a review of the literature. $J$ Cancer. 2011;2:206-9.
16. Papi G, Corrado S, Ruggiero C, LiVolsi VA. Solitary fibrous tumor of the thyroid gland associated with papillary thyroid carcinoma. Thyroid. 2006;16:319-20.

17. Bohorquez CL, Gonzalez-Campora R, Loscertales MC, Escudero AG, Mezquita JC. Solitary fibrous tumor of the thyroid with capsular invasion. Pathol Res Pract. 2003;199:687-90.

18. Rodriguez I, Ayala E, Caballero C, De Miguel C, Matias-Guiu X, Cubilla AL, et al. Solitary fibrous tumor of the thyroid gland. Am J Surg Pathol. 2001;25:1424-8.

19. Brunnemann RB, Ro JY, Ordonez NG, Mooney J, El-Naggar AK, Ayala AG. Extrapleural solitary fibrous tumor: a clinicopathologic study of 24 cases. Mod Pathol. 1999;12:1034-42.

20. Cameselle-Teijeiro J, Varela-Duran J, Fonseca E, Villanueva JP, Sobrinho-Simoes M. Solitary fibrous tumor of the thyroid. Am J Clin Pathol. 1994;101:535-8. 